\title{
Dual Fluorescence of 2-Methoxyanthracene Derivatives
}

Martin Albrecht, ${ }^{1}$ Cornelia Bohne, ${ }^{, 2}$ Anton Granzhan, ${ }^{3}$ Heiko Ihmels, ${ }^{* 3}$ Tamara C.S. Pace, ${ }^{2}$ Alexander Schnurpfeil,,${ }^{1,4}$ Michael Waidelich, ${ }^{3}$ Chang Yihwa ${ }^{2}$

\section{Supporting information}

Table S1. Parameters for the fluorescence lifetime measurements of 1a-1i. ${ }^{a}$

\begin{tabular}{|c|c|c|c|c|c|c|c|}
\hline Compd & $\begin{array}{l}\text { Concentration } \\
/ \mu \mathrm{M}\end{array}$ & Solvent & $\begin{array}{l}\lambda_{\mathrm{ex}} \\
/ \mathrm{nm}\end{array}$ & $\begin{array}{l}\lambda_{\mathrm{em}} \\
/ \mathrm{nm}\end{array}$ & $\tau_{1} / \mathrm{ns}(\%)$ & $\tau_{2} / \mathrm{ns}(\%)$ & $\chi^{2}$ \\
\hline $1 \mathbf{a}$ & 6.8 & $\mathrm{CH}_{3} \mathrm{OH}$ & 250 & 445 & 5.4 & - & 1.026 \\
\hline $1 \mathbf{a}$ & 6.8 & $\mathrm{CH}_{3} \mathrm{OH}$ & 250 & 400 & 5.3 & - & 1.043 \\
\hline $1 \mathbf{a}$ & 6.8 & $\mathrm{CH}_{3} \mathrm{OH}$ & 250 & 370 & 5.4 & - & 1.073 \\
\hline $1 \mathrm{~b}$ & 140 & $\mathrm{CH}_{3} \mathrm{OH}$ & 250 & 450 & 4.6 & - & 1.005 \\
\hline $1 \mathrm{~b}$ & 140 & $\mathrm{CH}_{3} \mathrm{OH}$ & 250 & 400 & 4.5 & - & 1.001 \\
\hline $1 \mathrm{~b}$ & 140 & $\mathrm{CH}_{3} \mathrm{OH}$ & 250 & 375 & 4.5 & - & 0.994 \\
\hline $1 \mathrm{c}$ & 19 & $\mathrm{CH}_{3} \mathrm{OH}$ & 250 & 450 & 3.5 & - & 1.026 \\
\hline 1c & 19 & $\mathrm{CH}_{3} \mathrm{OH}$ & 250 & 400 & 3.5 & - & 0.969 \\
\hline $1 \mathrm{c}$ & 19 & $\mathrm{CH}_{3} \mathrm{OH}$ & 250 & 375 & 3.5 & - & 1.006 \\
\hline 1d & 16 & $\mathrm{CH}_{3} \mathrm{OH}$ & 260 & 480 & $24.4(67)$ & $3.2(-33)$ & 1.070 \\
\hline 1d & 16 & $\mathrm{CH}_{3} \mathrm{OH}$ & 260 & 420 & 24.2 & - & 1.027 \\
\hline 1d & 16 & $\mathrm{CH}_{3} \mathrm{OH}$ & 260 & 400 & $24.1(38)$ & $3.2(62)$ & 1.088 \\
\hline 1d & 500 & $\mathrm{CH}_{3} \mathrm{OH}$ & 260 & 480 & $25.5(67)$ & $3.9(-33)$ & 1.145 \\
\hline 1d & 500 & $\mathrm{CH}_{3} \mathrm{OH}$ & 260 & 420 & 25.4 & - & 1.027 \\
\hline 1d & 500 & $\mathrm{CH}_{3} \mathrm{OH}$ & 260 & 400 & $24.8(38)$ & $3.7(62)$ & 1.088 \\
\hline $1 d^{b}$ & 16 & $\mathrm{CH}_{3} \mathrm{OH}$ & 260 & 480 & $10.8(68)$ & $2.6(-32)$ & 0.932 \\
\hline $1 d^{b}$ & 16 & $\mathrm{CH}_{3} \mathrm{OH}$ & 260 & 420 & 10.7 & - & 1.080 \\
\hline $1 d^{b}$ & 16 & $\mathrm{CH}_{3} \mathrm{OH}$ & 260 & 400 & $10.8(33)$ & $2.7(67)$ & 0.927 \\
\hline 1d & 15 & $\mathrm{CH}_{3} \mathrm{CN}$ & 260 & 480 & $26.5(84)$ & $5.2(-16)$ & 1.075 \\
\hline 1d & 15 & $\mathrm{CH}_{3} \mathrm{CN}$ & 260 & 420 & 26.4 & - & 1.172 \\
\hline 1d & 15 & $\mathrm{CH}_{3} \mathrm{CN}$ & 260 & 400 & $26.4(43)$ & $5.6(57)$ & 1.007 \\
\hline $1 d$ & 15 & $\mathrm{C}_{6} \mathrm{H}_{6}$ & 260 & 480 & $21.0(89)$ & $2.6(-11)$ & 1.094 \\
\hline 1d & 15 & $\mathrm{C}_{6} \mathrm{H}_{6}$ & 260 & 425 & 21.2 & - & 1.080 \\
\hline 1d & 15 & $\mathrm{C}_{6} \mathrm{H}_{6}$ & 260 & 400 & $21.0(51)$ & $2.5(49)$ & 1.042 \\
\hline $1 e$ & 12 & $\mathrm{CH}_{3} \mathrm{OH}$ & 260 & 480 & 22.5 (69) & $3.3(-31)$ & 1.027 \\
\hline 1e & 12 & $\mathrm{CH}_{3} \mathrm{OH}$ & 260 & 420 & 22.4 & - & 1.062 \\
\hline $1 e$ & 12 & $\mathrm{CH}_{3} \mathrm{OH}$ & 260 & 400 & $22.4(33)$ & $3.2(67)$ & 1.088 \\
\hline 1e & 146 & $\mathrm{CH}_{3} \mathrm{OH}$ & 260 & 480 & $26.0(68)$ & $4.0(-32)$ & 0.958 \\
\hline $1 e$ & 146 & $\mathrm{CH}_{3} \mathrm{OH}$ & 260 & 420 & 25.7 & - & 1.036 \\
\hline 1e & 146 & $\mathrm{CH}_{3} \mathrm{OH}$ & 260 & 400 & $25.5(38)$ & $3.9(62)$ & 0.938 \\
\hline $1 e^{b}$ & 13 & $\mathrm{CH}_{3} \mathrm{OH}$ & 260 & 480 & $10.6(69)$ & $3.0(-31)$ & 0.953 \\
\hline
\end{tabular}

${ }^{a}$ The values in parenthesis correspond to pre-exponential factors expressed in percentages when the decay was fit to the sum of two exponentials, negative values correspond to a growth kinetics; ${ }^{\text {b }}$ solutions containing air. 
Table S1. Continued

\begin{tabular}{|c|c|c|c|c|c|c|c|}
\hline Compd $^{\mathrm{d}}$ & $\begin{array}{l}\text { Concentration } \\
/ \mu \mathrm{M}\end{array}$ & Solvent & $\begin{array}{l}\lambda_{\mathrm{ex}} \\
/ \mathrm{nm}\end{array}$ & $\begin{array}{l}\lambda_{\mathrm{em}} \\
/ \mathrm{nm}\end{array}$ & $\tau_{1} / \mathrm{ns}(\%)$ & $\tau_{2} / \mathrm{ns}(\%)$ & $\chi^{2}$ \\
\hline $1 e^{b}$ & 13 & $\mathrm{CH}_{3} \mathrm{OH}$ & 260 & 420 & 10.7 & - & 1.043 \\
\hline $1 e^{b}$ & 13 & $\mathrm{CH}_{3} \mathrm{OH}$ & 260 & 400 & $10.9(41)$ & $3.1(59)$ & 1.059 \\
\hline 1e & 13 & $\mathrm{CH}_{3} \mathrm{CN}$ & 260 & 480 & $25.8(66)$ & $4.7(-34)$ & 1.061 \\
\hline 1e & 13 & $\mathrm{CH}_{3} \mathrm{CN}$ & 260 & 420 & 25.4 & - & 1.092 \\
\hline 1e & 13 & $\mathrm{CH}_{3} \mathrm{CN}$ & 260 & 400 & $25.9(41)$ & $5.9(59)$ & 1.082 \\
\hline $1 e$ & 13 & $\mathrm{C}_{6} \mathrm{H}_{6}$ & 260 & 480 & $20.3(90)$ & $2.5(-10)$ & 1.098 \\
\hline 1e & 13 & $\mathrm{C}_{6} \mathrm{H}_{6}$ & 260 & 425 & 20.2 & - & 1.088 \\
\hline 1e & 13 & $\mathrm{C}_{6} \mathrm{H}_{6}$ & 260 & 400 & $20.3(49)$ & $2.8(51)$ & 1.171 \\
\hline $1 \mathrm{f}^{\mathrm{a}}$ & 5.8 & $\mathrm{CH}_{3} \mathrm{OH}$ & 280 & 620 & $8.1(74)$ & $3.9(-26)$ & 1.005 \\
\hline $1 \mathrm{f}^{\mathrm{a}}$ & 5.8 & $\mathrm{CH}_{3} \mathrm{OH}$ & 280 & 530 & $8.4(82)$ & $2.5(18)$ & 1.003 \\
\hline $1 \mathrm{f}^{\mathrm{a}}$ & 5.8 & $\mathrm{CH}_{3} \mathrm{OH}$ & 280 & 450 & $8.7(41)$ & $3.0(59)$ & 0.992 \\
\hline $1 f^{a}$ & 5.8 & $\mathrm{CH}_{3} \mathrm{CN}$ & 280 & 550 & $13.0(71)$ & $4.9(-29)$ & 1.011 \\
\hline $1 f^{a}$ & 5.8 & $\mathrm{CH}_{3} \mathrm{CN}$ & 280 & 490 & $12.8(86)$ & $2.5(14)$ & 1.037 \\
\hline $\mathbf{1 f}^{\mathrm{a}}$ & 5.8 & $\mathrm{CH}_{3} \mathrm{CN}$ & 280 & 430 & $11.6(37)$ & $3.0(63)$ & 1.004 \\
\hline $1 f-F^{-c}$ & 5.8 & $\mathrm{CH}_{3} \mathrm{CN}$ & 280 & 510 & $18.0(70)$ & $5.4(-30)$ & 0.997 \\
\hline $1 f-F^{-c}$ & 5.8 & $\mathrm{CH}_{3} \mathrm{CN}$ & 280 & 440 & $17.8(81)$ & $5.0(19)$ & 0.997 \\
\hline $1 f-F^{-c}$ & 5.8 & $\mathrm{CH}_{3} \mathrm{CN}$ & 280 & 400 & $17.6(14)$ & $5.4(86)$ & 0.996 \\
\hline $\mathbf{1 f}^{\mathrm{a}}$ & 5.8 & $\mathrm{C}_{6} \mathrm{H}_{12}$ & 280 & 500 & $12.4(76)$ & $1.7(-24)$ & 1.023 \\
\hline $1 \mathrm{f}^{\mathrm{a}}$ & 5.8 & $\mathrm{C}_{6} \mathrm{H}_{12}$ & 280 & 440 & $12.4(82)$ & $1.0(18)$ & 0.997 \\
\hline $1 \mathrm{f}^{\mathrm{a}}$ & 5.8 & $\mathrm{C}_{6} \mathrm{H}_{12}$ & 280 & 410 & $12.1(19)$ & $1.1(81)$ & 1.007 \\
\hline $1 \mathrm{~g}^{\mathrm{c}}$ & 5.0 & $\mathrm{CH}_{3} \mathrm{OH}$ & 280 & 440 & $14.3(68)$ & $3.8(32)$ & 1.166 \\
\hline $1 \mathrm{~g}^{\mathrm{a}}$ & 5.0 & $\mathrm{CH}_{3} \mathrm{OH}$ & 380 & 440 & $14.4(69)$ & $3.7(31)$ & 1.067 \\
\hline $1 \mathrm{~g}^{\mathrm{a}}$ & 5.0 & $\mathrm{SDS}^{\mathrm{d}}$ & 290 & 440 & $12.5(63)$ & $3.7(37)$ & 0.990 \\
\hline $1 \mathrm{~g}^{\mathrm{b}}$ & 5.0 & $\mathrm{CH}_{3} \mathrm{OH}$ & 280 & 510 & $12.9(78)$ & $2.6(-22)$ & 0.997 \\
\hline $1 \mathrm{~g}^{\mathrm{c}}$ & 5.0 & $\mathrm{CH}_{3} \mathrm{OH}$ & 280 & 440 & $12.4(62)$ & $3.6(38$ & 0.979 \\
\hline $1 \mathrm{~g}^{\mathrm{b}}$ & 5.0 & $\mathrm{CH}_{3} \mathrm{OH}$ & 280 & 410 & $11.4(13)$ & $3.6(87)$ & 0.992 \\
\hline $1 g-H^{+e}$ & 5.0 & $\mathrm{CH}_{3} \mathrm{OH}$ & 310 & 580 & 8.9 & - & 1.047 \\
\hline $1 \mathrm{~g}-\mathrm{H}^{+\mathrm{e}}$ & 5.0 & $\mathrm{CH}_{3} \mathrm{OH}$ & 310 & 540 & $8.2(80)$ & $2.7(20)$ & 0.999 \\
\hline $1 g-H^{+e}$ & 5.0 & $\mathrm{CH}_{3} \mathrm{OH}$ & 310 & 490 & $8.1(46)$ & $2.7(54)$ & 1.008 \\
\hline $1 g-H^{+e}$ & 5.0 & $\mathrm{CH}_{3} \mathrm{OH}$ & 290 & 500 & $9.5(52)$ & $3.2(48)$ & 0.970 \\
\hline $1 \mathrm{~h}$ & 5.2 & $\mathrm{CH}_{3} \mathrm{OH}$ & 280 & 510 & $8.4(80)$ & $2.9(-20)$ & 1.025 \\
\hline $1 \mathrm{~h}$ & 5.2 & $\mathrm{CH}_{3} \mathrm{OH}$ & 280 & 440 & $8.4(65)$ & $2.4(35)$ & 0.968 \\
\hline $1 \mathrm{~h}$ & 5.2 & $\mathrm{CH}_{3} \mathrm{OH}$ & 280 & 410 & $8.3(16)$ & $2.4(84)$ & 0.978 \\
\hline $1 h^{\mathrm{a}}$ & 5.2 & $\mathrm{CHCl}_{3}$ & 290 & 480 & $6.5(80)$ & $1.6(-20)$ & 0.963 \\
\hline $\mathbf{1 h}^{\mathrm{a}}$ & 5.2 & $\mathrm{CHCl}_{3}$ & 290 & 440 & $6.3(80)$ & $2.3(20)$ & 0.970 \\
\hline $\mathbf{1 h}^{\mathrm{a}}$ & 5.2 & $\mathrm{CHCl}_{3}$ & 290 & 410 & $6.1(17)$ & $2.0(83)$ & 0.955 \\
\hline $1 \mathrm{~h}-\mathrm{H}^{+e}$ & 5.2 & $\mathrm{CHCl}_{3}$ & 320 & 600 & $6.3(82)$ & $1.5(-18)$ & 0.974 \\
\hline
\end{tabular}

${ }^{\mathrm{a}}$ The values in parenthesis correspond to pre-exponential factors expressed in percentages when the decay was fit to the sum of two exponentials, negative values correspond to a growth kinetics; ${ }^{\mathrm{b}}$ solutions containing air; ${ }^{\mathrm{c}}\left[\mathrm{F}^{-}\right]=1.5 \mathrm{mM} ;{ }^{\mathrm{d}}[\mathrm{SDS}]=0.1 \mathrm{M} \mathrm{SDS}=$ sodium dodecyl sulfate; ${ }^{\mathrm{e}} \mathrm{pH} \approx 2$ (addition of aq. $\mathrm{HCl}$ ). 
Table S1. Continued

\begin{tabular}{llllllll}
\hline Compd $^{\mathrm{d}}$ & $\begin{array}{l}\text { Concentration } \\
\text { / S M }\end{array}$ & Solvent & $\begin{array}{l}\lambda_{\text {ex }} \\
/ \mathrm{nm}\end{array}$ & $\begin{array}{l}\lambda_{\text {em }} \\
/ \mathrm{nm}\end{array}$ & $\tau_{1} / \mathrm{ns}(\%)$ & $\tau_{2} / \mathrm{ns}(\%)$ & $\chi^{2}$ \\
\hline $\mathbf{1 h}-\mathbf{H}^{+\mathbf{e}}$ & 5.2 & $\mathrm{CHCl}_{3}$ & 320 & 530 & $6.1(82)$ & $1.9(18)$ & 1.010 \\
$\mathbf{1 h}-\mathbf{H}^{+\mathbf{e}}$ & 5.2 & $\mathrm{CHCl}_{3}$ & 320 & 490 & $6.0(58)$ & $2.0(42)$ & 1.005 \\
$\mathbf{1 i}$ & 17 & $\mathrm{CH}_{3} \mathrm{CN}$ & 280 & 400 & 6.7 & - & 1.030 \\
$\mathbf{1 i}$ & 17 & $\mathrm{CH}_{3} \mathrm{CN}$ & 280 & 440 & 6.7 & - & 1.058 \\
$\mathbf{1 i - F ^ { - \mathbf { f } }}$ & 17 & $\mathrm{CH}_{3} \mathrm{CN}$ & 280 & 400 & 6.5 & - & 1.112 \\
$\mathbf{1 i - F ^ { - \mathbf { f } }}$ & 11 & $\mathrm{CH}_{3} \mathrm{CN}$ & 280 & 440 & 6.5 & - & 1,158 \\
$\mathbf{1 i}-\mathbf{F}^{-\mathbf{f}}$ & 11 & $\mathrm{CH}_{3} \mathrm{CN}$ & 363 & 510 & 6.6 & - & 1.042 \\
\hline
\end{tabular}

${ }^{a}$ The values in parenthesis correspond to pre-exponential factors expressed in percentages when the decay was fit to the sum of two exponentials, negative values correspond to a growth kinetics; ${ }^{\mathrm{b}}$ solutions containing air; ${ }^{\mathrm{c}}\left[\mathrm{F}^{-}\right]=1.5 \mathrm{mM} ;{ }^{\mathrm{d}}[\mathrm{SDS}]=0.1 \mathrm{M} \mathrm{SDS}=$ sodium dodecyl sulfate; ${ }^{\mathrm{e}} \mathrm{pH} \approx 2$ (addition of aq. $\mathrm{HCl}$ ); ${ }^{\mathrm{f}}\left[\mathrm{F}^{-}\right]=11 \mu \mathrm{M}$.

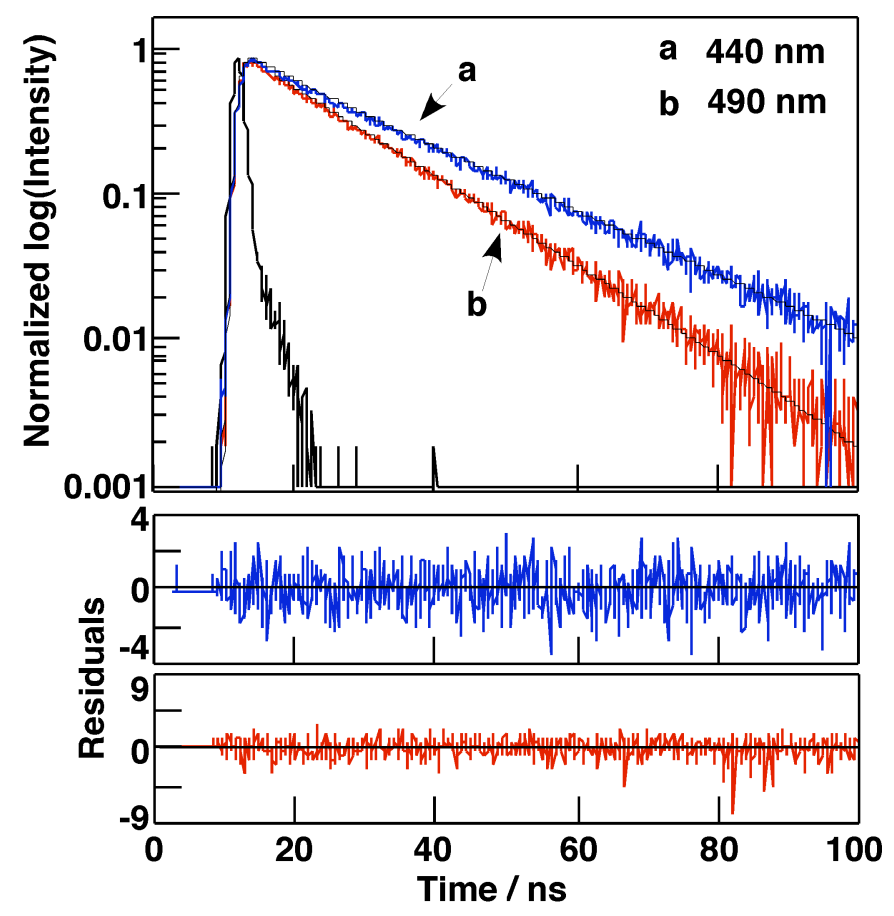

Figure S1. Fluorescence decay of $1 \mathrm{f}(5.8 \mu \mathrm{M})$ in acetonitrile in the presence of fluoride (a, blue, $\left.\lambda_{\mathrm{ex}}=280 \mathrm{~nm}, \lambda_{\mathrm{em}}=440 \mathrm{~nm},\left[\mathrm{~F}^{-}\right]=1.5 \mathrm{mM}\right)$ and absence of fluoride $\left(\mathrm{b}\right.$, red, $\lambda_{\mathrm{ex}}=280 \mathrm{~nm}, \lambda_{\mathrm{ex}}=490$ $\mathrm{nm}$ ). The IRF data are shown in black. The solid line (black) corresponds to the fit of the experimental data to the sum of two exponentials. The residuals between the data and the fits are shown below the

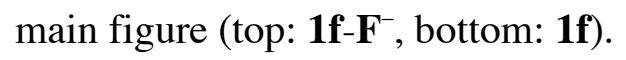




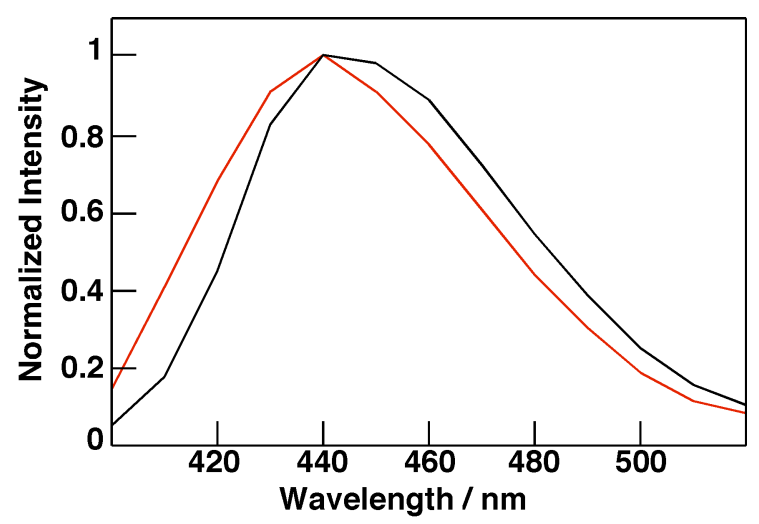

Figure S2. Time resolved emission spectra (TRES) of $\mathbf{1 f}$ in acetonitrile $\left(5.8 \mu \mathrm{M}, \boldsymbol{\lambda}_{\mathrm{ex}}=280 \mathrm{~nm}\right)$ in the presence of fluoride $(1.5 \mathrm{mM})$ integrated between delays after the onset of the emission of 0 and $20 \mathrm{~ns}$ (red) and between delays of 40 and 180 ns (black).

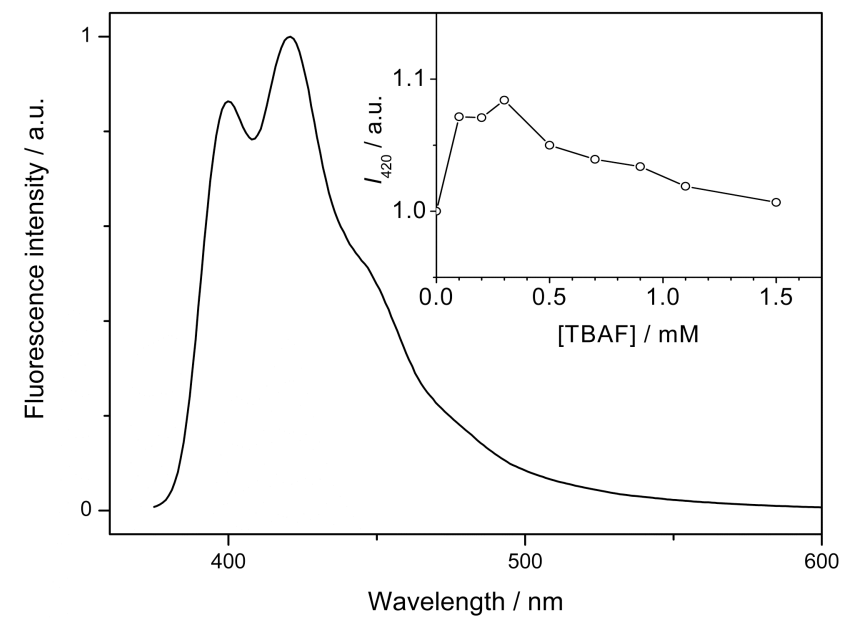

Figure S3. Fluorescence emission spectrum of $\mathbf{1 i}\left(10 \mu \mathrm{M}\right.$ in $\mathrm{MeCN}$, excitation wavelength $\lambda_{\mathrm{ex}}=363$ $\mathrm{nm})$. The inset shows the changes of the relative fluorescence intensity upon addition of TBAF. 


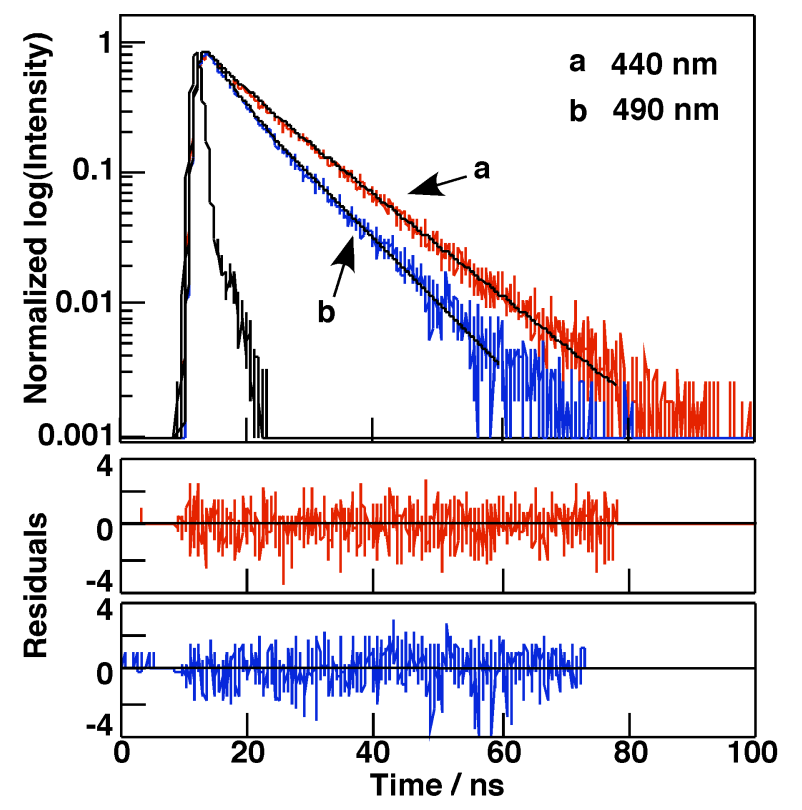

Figure S4. Fluorescence decay of $1 \mathrm{~g}\left(5.0 \mu \mathrm{M}\right.$ in methanol) in the absence (a, red, $\lambda_{\mathrm{ex}}=280 \mathrm{~nm}, \lambda_{\mathrm{em}}=$ $440 \mathrm{~nm})$ and the presence of $\mathrm{HCl}\left(\mathrm{b}\right.$, blue, $\lambda_{\mathrm{ex}}=310 \mathrm{~nm}, \lambda_{\mathrm{em}}=490 \mathrm{~nm} \mathrm{pH} \mathrm{2).} \mathrm{The} \mathrm{IRF} \mathrm{is} \mathrm{shown} \mathrm{in}$ black. The solid line (black) corresponds to the fit of the experimental data to the sum of two exponentials. The residuals between the data and the fits are shown below the main figure (top: 1g, bottom: $\left.\mathbf{1 g}-\mathbf{H}^{+}\right)$. 


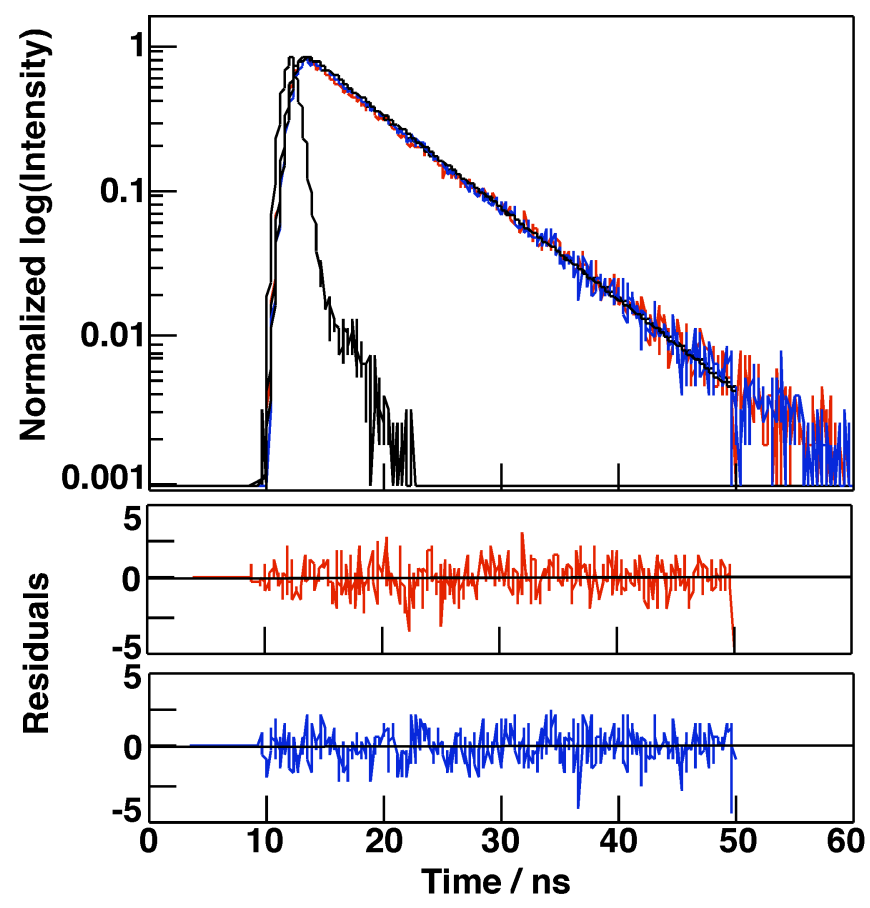

Figure S5. Fluorescence decay of $\mathbf{1 h}\left(5.2 \mu \mathrm{M}\right.$ in $\left.\mathrm{CHCl}_{3}\right)$ in the absence (red, $\lambda_{\mathrm{ex}}=290 \mathrm{~nm}, \lambda_{\mathrm{em}}=440$ $\mathrm{nm}$ ) and the presence of $\mathrm{HCl}$ (blue, $\lambda_{\mathrm{ex}}=320 \mathrm{~nm}, \lambda_{\mathrm{em}}=530 \mathrm{~nm}, \mathrm{pH} \sim 2$ ). The IRF is shown in black. The solid line (black) corresponds to the fit of the experimental data to the sum of two exponentials. The residuals between the data and the fits are shown below the main figure (top: $\mathbf{1 h}$, bottom: $\mathbf{1 h}-\mathbf{H}^{+}$).

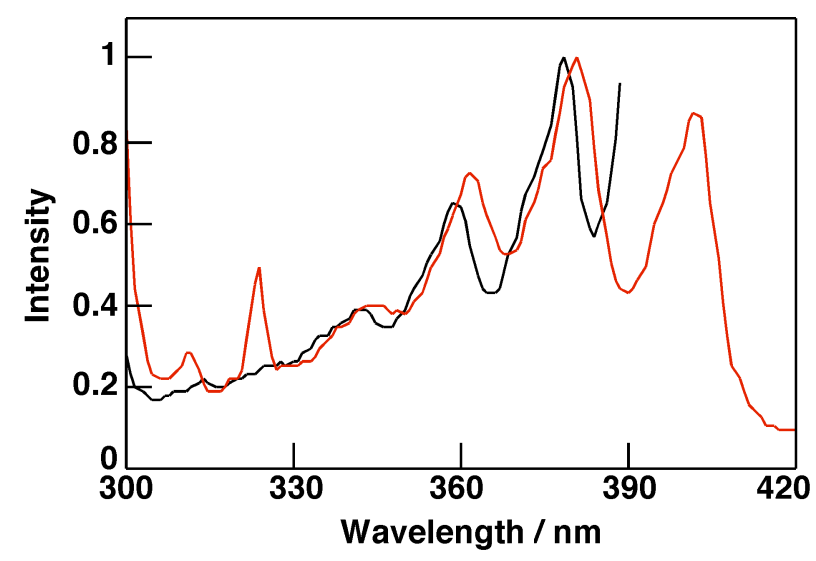

Figure S6. Fluorescence excitation spectra for $1 \mathrm{~g}\left(5.0 \mu \mathrm{M}\right.$ in toluene) at $77 \mathrm{~K}$ (red, $\lambda_{\mathrm{em}}=460 \mathrm{~nm}$; black, $\lambda_{\mathrm{em}}=400 \mathrm{~nm}$ ), the spectrum above $390 \mathrm{~nm}$ could not be collected because it coincides with the emission wavelength. 
Table S2. Lifetime for $\mathbf{1 d}$ in cyclohexane at various temperatures. ${ }^{a}$

\begin{tabular}{llll}
\hline $\mathrm{T} /{ }^{\circ} \mathrm{C}$ & $\lambda_{\mathrm{em}} / \mathrm{nm}$ & $\tau_{1} / \mathrm{ns}$ & $\tau_{2} / \mathrm{ns}$ \\
\hline 10 & 400 & 20.4 & 3.11 \\
10 & 425 & 20.9 & - \\
10 & 480 & 20.8 & 3.35 \\
20 & 400 & 21.1 & 2.12 \\
20 & 425 & 21.3 & - \\
20 & 480 & 21.5 & 2.66 \\
45 & 400 & 20.7 & 1.07 \\
45 & 425 & 20.7 & - \\
45 & 480 & 20.9 & 1.24 \\
60 & 400 & 21.5 & 0.81 \\
60 & 425 & 21.4 & - \\
60 & 480 & 21.6 & 1.11 \\
${ }^{\mathrm{a}}, \lambda_{\mathrm{ex}}=260 \mathrm{~nm}$. & & \\
& & &
\end{tabular}

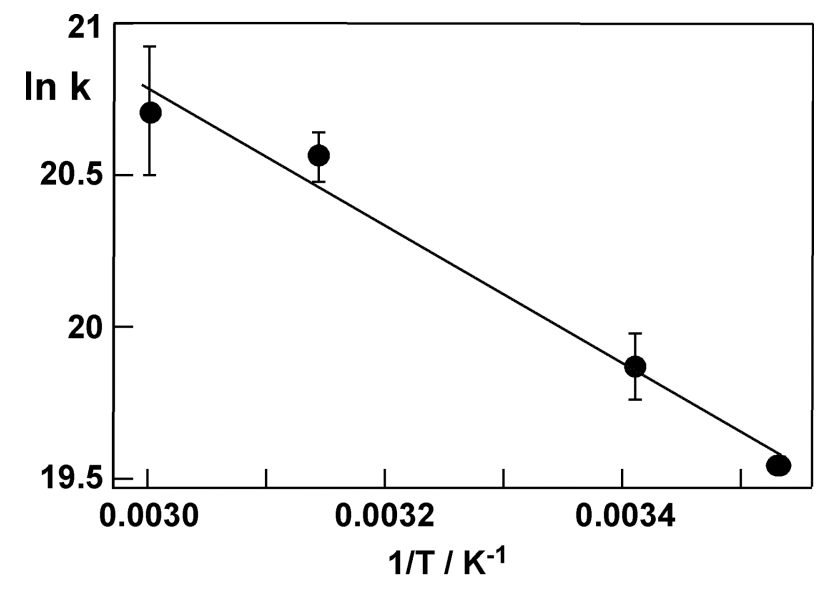

Figure S7. Dependence of the short lifetime for $\mathbf{1 d}$ in cyclohexane on the temperature. The recovered value for $\mathrm{E}_{\mathrm{a}}$ is $19 \pm 2 \mathrm{~kJ} / \mathrm{mol}$. 